\title{
TNSTANCES OF KINGSHIP IN SVERRIS SAGA
}

\section{Costel Coroban}

“Valahia" University of Târgoviște, E-mail: coroban_costel@yahoo.com

\section{Acknowledgements}

This paper was presented at the Sixth international conference on Baltic and Nordic Studies in Romania Historical memory, the politics of memory and cultural identity: Romania, Scandinavia and the Baltic Sea Region in comparison, organized by the Romanian Association for Baltic and Nordic Studies, Faculty of History and Political Sciences of Ovidius University of Constanța and International Summer School of The University of Oslo, Norway, May 22-23, 2015. Supported by a grant from Iceland, Liechtenstein and Norway, The EEA Fund for Bilateral Relations, contract no. 910/20.03.2015.

This paper has been prepared with the financial support of the project "Quality European Doctorate - EURODOC", Contract no. POSDRU/187/1.5/S/155450, project co-financed by the European Social Fund through the Sectoral Operational Programme "Human Resources Development" 2007-2013.

\begin{abstract}
:
The methodology proposed in this article is that of historical research, which is understood as the formulation or identification of a research topic, followed by literature review and sources' collection, assessment of the sources in an order that is logical and/or chronological, information and findings' synthesis, and finally the narrative exposition of the research results and the finding of a general conclusion that draws on the finds of each segment of the research. Regarding the formula "instances of kingship" in the title, the concept of ideology plays an important role in the current research as one of the premises of the study is that power relations are embedded in it. The term ideology is to be taken in consideration in its political meaning, which is why I have chosen the formula "ideology of power". The premise of the current thesis is that political behaviour is shaped by pre-existing ideology, which is not always logical yet it holds great meaning for the society under examination. The concept of political power includes a suite of levels of analysis: the discussion of the transformation of power (whether it is conferred, delegated, shared or limited), the way power is exerted (either through consent or coercion), what power relies on (coercion or influence) and possibly whether it flows from authority,
\end{abstract}


legitimacy, or right. The source to be used in the purpose of discerning the characteristics of royalty in Norway is Sverris saga, which represents a unique source among the kings' sagas, since it is entirely dedicated to the rule of one king.

\section{Rezumat:}

In acest articol, metodologia propusă este cea a cercetării istorice, înțeleasă prin formularea unei întrebări de cercetare, urmată de analiza studiilor şi surselor identificate într-o ordine logică sau cronologică, sintetizarea informațiilor şi răspunsurilor descoperite şi, în final, expunerea rezultatelor cercetării şi formularea unei concluzii generale care să fie în acord $c u$ ceea ce s-a formulat în fiecare segment al cercetării. În ceea ce priveşte sintagma "instanțe ale regalității” din titlu, conceptul de ideologie joacă un rol important în cercetarea de față deoarece se porneşte de la faptul că relațiile de putere sunt intrinseci ideologiei. Termenul de ideologie trebuie înțeles în sensul său politic, de aceea alegând formula "ideologia puterii". Una din premisele tezei este faptul că politica şi comportamentul politic se bazează pe o ideologie pre-existentă, care nu se întemeiază întotdeauna pe rațiune insă are o mare importanță pentru societatea în cauză. Conceptul de putere politică include un număr mare de nivele de analiză: analiza transformărilor suferite de putere (atunci când este conferită, delegată, împărțită sau limitată), felul în care este exercitată (prin constrângere sau consimțământ) şi dacă aceasta decurge din autoritate, legitimitate sau din lege. Sursa ce a fost inclusă în analiză este Sverris saga, un izvor unic datorită faptului că este prima saga dedicată $\hat{\imath}$ întregime domniei unui singur rege.

Keywords: Sverris saga, Sverrir Sigurðarson, kings' sagas, ideology, power, kingship

\section{Introduction: King Sverrir and den borgerkrigstiden}

Sverris saga, ${ }^{1}$ fits the category of kings' sagas (konungasogur), and is set in the period of King Sverrir Sigurðarson (c. 1145/1151 - 9 March 1202). It coveys a multitude of information regarding political power and kingship in Norway and as such is one of the first sources that will be analysed in this chapter. Unlike the other sagas, the first part of Sverris saga has been

\footnotetext{
1 The edition used in the current analysis is J. Stephton's translation: Sverrissaga - The Saga of King Sverri of Norway (London: David Nutt, 1899), henceforth Sverris saga; original medieval manuscripts of Sverris saga now exist in four copies: A.M. 327, 4to at the University Library of Copenhagen (dating back to cca. 1300), A.M. 47 fol also at the University Library of Copenhagen (dating to the early $14^{\text {th }}$ century), Flateyiar-bok at the Royal Library at Copenhagen (written in Iceland in the late 14th century) and A.M. 81a fol. at the University Library of Copenhagen (middle $15^{\text {th }}$ century).
} 
written while the king was sovereign (somewhere between 1185 to $1188^{2}$ ), so this makes most of it contemporary to the events described and confirms its significance. Furthermore, the first part of Sverris saga, called Grýla (i.e. "bugbear"), was anecdotally put to paper by the abbot Karl Jónsson while King Sverrir was dictating, which might permit a direct analysis of the ideology of power in Norway based on the opinions and beliefs of a king.

To understand the context it was written in, it best to offer some clarifications about the political milieu in Norway at that time. The period is called the Civil war era, a term which denotes the period from about 1130 to the middle of the $13^{\text {th }}$ century. It was an age of frequent battling between rival kings, princes and pretenders to the throne of Norway and its cause is still a reason for debate among historians today. Nevertheless, it is useful to look back to King Harald Hárfagri's (c. 850 - c. 932) unification of Norway after the battle of Hafrsfjord (872) as the beginning of the struggle to bring Norway under a strong centralized command. Also, the role of the Church in sometimes promoting division should also be taken into consideration. What is noteworthy about political power during this period is that it was shareable whenever there was more than one claimant to the throne (brothers or cousins), as succession laws were not clear, which often resulted in struggle for dominance between the two co-rulers.

Until the rule of King Sverrir, these power struggles were often quite modest, involving small scale forces, namely the hird entourage of the kings or pretenders plus personal army contingents (lendir menn) and local armed men that might have been persuaded to join the wars. After 1170, with the clear distinction of the rival faction of the Birkibeinar, ${ }^{3}$ the fighting for the throne assumed a more distinct civil war character, which created consequences for the entire community in Norway. ${ }^{4}$ It is possible that under this kind of pressure that the political ideology of Norwegian kingship suffered great changes, which supports the necessity of including Sverris saga in the present research.

\footnotetext{
2 Sverre Bagge, "Ideology and Propaganda in Sverris saga" Arkiv för nordisk filologi 108 (1993), 1-18.

${ }^{3}$ Birkibeinar, meaning "birch legs", a pejorative reference to the alledged poverty of the members of this movement, formed in 1174 under the leadership of the pretender Øystein Møyla.

4 Knut Helle, ed., The Cambridge History of Scandinavia. Prehistory to 1520 (Cambridge: CUP, 2008), 374.
} 
The saga begins with the account of Sverrir's birth, which as in many sagas - and many hagiographies as well - is a supernatural event: his mother receives a strange vision upon the moment of delivery and the midwife is frightened. Thus, Sverrir is destined for great feats from the very moment he enters the world, which may be interpreted as a desirable background of a charismatic king. Some have made a parallel between the miraculous in King Sverrir's saga and the miracles of the Bible 5 , and have seen in Sverrir the image of David, who is a saviour that overcomes great odds to save his people in a critical time.

The saga continues with the moving to the Faeroe Islands when Sverrir was aged five. There, he lived in the care of his uncle, the bishop of the Faeroe, and in time was himself ordained priest. Since it was rather uncommon for priests to be ordained at such frail ages, perhaps this detail was included by the king later in order to prove his suitability to rule a Christian kingdom. Relating to this, on one occasion Sverrir dreams "that he was in Norway, and was become a bird, so large that its beak reached the boundaries of the land in the east, and the feathers of its tail as far north as the dwellings of the Finns, while its wings covered the whole country." 6 A wise-man then told the future king that this might symbolize his becoming archbishop, which Sverrir dismissed stating he did not even possess the quality of a priest. It is possible that the "large bird" mentioned here is the eagle, which signified both strength and death in Norse mythology since it ate the dead bodies after a battle. In the Eddas Oðin is often depicted with an eagle or takes the form of an eagle, and there is a connection to warrior ideology 7 , so this might explain the choice of the author of the saga for identifying the aspiring prince with this totem.

\section{Sverrir and Saint Óláfr}

Óláfr Haraldsson, who would become known as Saint Óláfr, declared himself the king of Norway in 1015 and secured the title after successfully defeating Jarl Sveinn Hákonarson at the battle of Nesjar in 1016. Saint Óláfr

\footnotetext{
5 See, for example, David Bond West, Biblical Allusions in Sverris Saga, MA dissertation in Medieval Icelandic Studies, Hugvísindasvið, Háskóli Íslands University, 2012.

6 Sverris saga, chapter 2.

7 Anne-Sofie Gräslund, "Wolves, serpents, and birds, Their symbolic meaning in the Old Norse belief," in Andrén, Anders; Jennbert, Kristina et al., eds., Old Norse Religion in LongTerm Perspectives: Origins, Changes, and Interactions (Lund: Nordic Academic Press), 127, (p 124-129).
} 
became a national symbol of Norway after continuing the conversion of Norway began by Óláfr Tryggvason and earning the reputation of a pious and just monarch. His harsh rule became disliked by Norwegians who rebelled, which offered Knútr ríki Sveinsson (Canute the Great of Denmark and England) the opportunity to invade Norway. Saint Óláfr initially fled eastwards, where he famously baptised many, and returned with an army to retake his kingdom. ${ }^{8}$ He perished in the battle of Stiklarstaðir on 29 July 1030 and was canonised by Bishop Grimkell, whom he had brought from England, in Nidaros. In the later Historia Norwegiae ${ }^{9}$ he was given the title Rex Perpetuus Norvegiae in recognition for the renown, and his symbol, the axe, appears on the Norwegian coat of arms. It therefore becomes evident why King Sverrir wanted to be seen as the protected by Saint Óláfr, who symbolized Norway. Having the sympathy of Saint Óláfr meant ruling Norway.

It is also possible that he was aware of his rival's, King Magnús, claim that he was the humble vassal of Saint Óláfr who was ruling Norway as a fief in the name of the holy king:

“...I bequeath my person and my kingdom to God for ever and ever; and by a special act of sacrifice I commit the kingdom of Norway wholly to the noble martyr King Olav, who is next after the Lord. And God's favour permitting, I shall manage this kingdom as the noble martyr's inheritance, under his feudal majesty and as his deputy and vassal. And because this martyr fearlessly went to meet his enemies in battle to uphold the law of his God, for the salvation of his people, and to safeguard this kingdom, and because he unhesitatingly gave himself into the hands of evil people, he sanctified this kingdom by his precious blood. I therefore wish to be his follower in ruling this kingdom and, as far as my strength will allow, to imitate his virtues with help from God and this same martyr; and whatever need, lacks or tribulations I may encounter, I will fearlessly fight for the cause of justice and defend the country as St Olav's property, confident through God's and his protection, and I

\footnotetext{
8 Carl Phelpstead, ed., Devra Kunin, trans., A History of Norway and the Passion and Miracles of the Blessed Óláfr (London: University College London, 2001), xxv.

${ }^{9}$ A brief history of Norway written by an anonymous monk. The existing copy dates from the beginning of the $16^{\text {th }}$ century but the original is thought to have been written around 1150-1175, see Inger Ekrem, ed., Lars Boje Mortensen, ed., Peter Fisher, trans., Historia Norwegie (Copehangen: Museum Tusculanum Press, University of Copenhagen, 2006).
} 
will fight under his leadership, as his knight and in his army; and though a host should rise up against me, my heart shall not fear." 10

Here we see how Magnús Erlingsson vows to rule Norway as a gift from Saint Óláfr and to rule as a knight of him and after his model of sacrifice as a martyr. Some scholars have pointed out that such an oath would cancel anyone else's claims to the throne of Norway in a very convenient and pious manner ${ }^{11}$.

In a similar fashion, a dream of Sverrir that is also representative for his perception of what a monarch should stand for is the one in which he joins King Saint Óláfr in battle against King Magnús and Earl Erlingr. Saint Óláfr bestows gifts upon him, much like a lord does to his vassal, and rejoices when Sverrir joins his side, as he had become a great mean, having been previously "chosen to be bishop most likely." 12 While in Saint Óláfr's entourage he receives the honour of washing his face in the bowl the king used, which probably points to the nobility of Sverrir, who alone receives such an honour. Furthermore, during an assault, the king offers Sverrir his sword and his banner and instructs his people to arms themselves, promising to protect them with only his shield. Then, at the confrontation with King Magnús and Earl Erlingr, the enemy army is obliterated as soon as the attack against them is made by the host carrying the flag. There are debates about how this fragment should be understood. It is probable that Sverrir wanted to identify himself with Saint Óláfr due to his renown as the most determined converter of Norway and the impact this made on the political imagination of the Norwegians and his recognition as the patron saint of the country. ${ }^{13}$ If it is indeed true that King Sverrir himself dictated this part of the saga that bears his name, then he did so in order to identify himself with the throne of Norway from the earliest times and in extraordinary circumstances. Sverre Bagge considers this episode typical to the tone of a medieval hagiography and attributes such miracles to the need of showing that King Sverrir is the ideal ruler not because of his superior political programme or his royal lineage, but simply because of his

\footnotetext{
10 Privilegiebrev (Letter of Privilege) of King Magnús Erlingsson, issued not long after his coronation. Translation taken from Inger Ekrem (ed.) et al., 209.

11 For a discussion of the letter in European context see Haki Antonsson, St. Magnús of Orkney, A Scandinavian Martyr-Cult in Context (Leiden: Brill, 2007), 218.

12 Sverris saga, chapter 5 .

${ }^{13}$ Katherine Holman, The A to Z of the Vikings (Plymouth: The Scarecrow Press, 2009), 206.
} 
outstanding success ${ }^{14}$. After all, luck and success, no matter by which means, were extremely important for the Vikings as well, and victory was valued above all else ${ }^{15}$.

When the saga tells the episode of Sverrir's battle with the lords (höfðingjar) and yeomen of Nidaros, it is said that the enemy army "showed such audacity ... that they took the banner of King Óláfr the Saint, to bear it against King Sverrir"16. Furthermore, the horsemen carrying the banner were immediately lost in the ensuing battle, a sign that the ideals of King Sverrir owed so much to Saint Óláfr that his artefact could not be used against the former. After assuring victory King Sverrir captures the banner and delivers it to the city, thanking God, the Holy Virgin and Saint Óláfr for his victory, in spite of the ambush set up by the warriors of Nidaros, to which he magnanimously gives quarter.

King Sverrir asks for Saint Óláfr's help on many occasions. He asks for the saint's blessing when launching his new ship, Maríusúðin, as well17. When his fleet was surrounded at Stad by that of King Magnús, Jarl Erling and Archbishop Eystein, Sverrir "bettok himself therefore to prayer, and called upon King Óláfr the Saint, pleading form his men with much eloquence. And at that instant a mist came down on the sea, so thick that they could not see form one ship to another"18. What followed was that Sverrir was able to escape the blockade unharmed thanks to this more than biblical wonder.

King Sverrir occasionally appeals to a different local Norwegian saint: Sunniva, as well as to God and the Virgin directly. Saint Sunniva (Sunnifa, Synøve) is worshipped on the west coast of Norway and was a woman of Irish or English descent who settled there in order to avoid marrying a pagan chief ${ }^{19}$. She is part of the important anti-pagan and proChristianisation effort in $10^{\text {th }}$ century Norway that is patronized by Saint Óláfr, She is also asked to interecede with Jesus in Hakon Hakonarsonar saga when Hakon's mother has to face the ordeal of the iron ${ }^{20}$.

\footnotetext{
14 Sverre Bagge, "Ideology and Propaganda in Sverris saga”, 3.

15 See Bettina Sejbjerg Sommer, „The Norse Concept of Luck” Scandinavian Studies 79, 3 (Fall 2007), 275-294.

16 Sverris Saga, chapter 15.

17 Sverris saga, chapter 80 .

18 Sverris saga, chapter 32.

19 "Saint Sunniva of Bergen". CatholicSaints.Info. 4 July 2015. Web. 13 August 2015. http:/ / catholicsaints.info/tag/name-sunnifa/.

${ }^{20}$ Hakon Hakonarsonar saga, chapter 44.
} 


\section{Sverrir the military man}

After his first vision of Saint Óláfr, Sverrir receives the petition of the Birkibeinar who beg him to assume their leadership after finding out of his royal lineage ${ }^{21}$. They are disappointed because Sverrir was reluctant to accept, perhaps being himself quite unsure of his mother's reassurances that he was the son of King Sigurðr munnr ${ }^{22}$. The second time he is asked to lead the group, Sverrir is again disposed to decline but this time he is offered two choices, to lead them or to lose his life. After accepting to lead the Birkibeinar there comes another episode of a dream that confers legitimation. This time, Sverrir encounters the prophet Samuel who anoints him and bids him to "be strong and valiant, for God will give thee help" 23 . Samuel is the prophet that anointed David of the Israelites so perhaps this reference hints at the unfavourable odds that Sverrir must face to take the throne from King Magnús Erlingsson ${ }^{24}$. Whether this reference was introduced by the king himself or by the abbot the implication is that the divinity intervened to take away any doubt Sverrir might have had about his abilities as a ruler and to confer him legitimacy in an unique way, as he had refused claiming the throne through an ordeal as claimants usually did. Perhaps this refusal to undergo an ordeal was a consequence of his modest earlier life, which he mentions as a reason for not wishing to lead the Birkibeinar on the first occasion he is asked.

In his military exploits, the king is prudent, resourceful and gives those who ask quarter. To cite one example, on the occasion of the invasion of Haðaland he is able to raise 20 marks of gold and when faced with the ill-equipped army of the local yeomen, he shows them mercy when they hesitate to engage his forces, despite probably knowing they would spread the new of his invasion. On a different occasion, in contrast to King Sverrir, Jarl Erling, who was a supporter of King Magnús, advises his men not to give quarter to the Birkineinar, reminding them of the deeds that the latter

\footnotetext{
21 The rule that any male descendant of the king could be recognized as king by an assembly was what pushed the Birkibeinar towards Sverrir. Sverre Bagge, From Viking Stronghold to Christian Kingdom, State Formation in Norway, c. 900-1350 (Copenhagen: Museum Tusculanum Press, 2010), 40.

22 Ibid.

23 Sverris saga, chapter 10 .

24 David Bond West, 1-2.
} 
have done to them. ${ }^{25}$ To give another example, before the battle in Sogn, Ásbjörn Jónsson, one of King Magnús's warriors, holds a speech in which he urges the king's soldiers to "deal heavy strokes at all before us, careless where the blows fall, for we use no care in chopping meat for dogs or ravens" ${ }^{26}$. This is in contrast to King Sverrir's usual care for yeomen that are in the enemy army to not be hurt by the Birkibeinar.

Back in Haðaland, foreseeing the treason of the yeomen he showed mercy, Sverrir had his men fell trees and to use as rollers in order to drag his ships to the sea and make a surprise attack against the jarls, which he defeated with God's aid, the saga mentions ${ }^{27}$. On his march to Bergen, when he is faced with unfavourable odds, the king advises his men to take cover and takes the enemy by surprise ${ }^{28}$. Even when facing the united forces of Vors, the king's Birkibeinar are able to secure victory despite being outnumbered ${ }^{29}$. The same situation repeats when King Sverrir takes five men, and for being "the nobler man", is able to capture Thorgrim, a supporter of King Magnus, and his eight húskarlar ${ }^{30}$. At Sogn when the king sees that Magnús's ships are outnumbering his, he quickly dispatches messengers to the rest of his forces in Sóknadal and urges his men to make sure no projectile would be thrown in vain and to protect themselves, taking advantage of the high bulwarks of their ships ${ }^{31}$.

At the night attack of the Jamtr against King Sverrir near Helsíngjaland, he uses his wits and lets his enemies slaughter each other until dawn breaks, knowing they would not be able to distinguish between their own men and his Birkibeinar, thus being able to escape their large force of twelve hundred men ${ }^{32}$. Then the king ponders whether he should invade Ireland, as that would diminish the prestige of King Magnús and increase his own ${ }^{33}$. Similarly to the previous night attack, at Vik the King Sverrir himself bravely leads 6 scouts in setting an ambush which successfully routs a host of King Magnús leaving many victims behind ${ }^{34}$.

\footnotetext{
25 Sverris saga, chapter 31.

26 Sverris saga, chapter 90 .

27 Sverris saga, chapter 16 .

28 Sverris saga, chapter 18 .

29 Sverris saga, chapter 19.

30 Sverris saga, chapter 21 .

31 Sverris saga, chapter 88 .

32 Sverris saga, chapter 26.

33 Sverris saga, chapter 27.

34 Sverris saga, chapter 31 .
} 
King Sverrir is no stranger from ambush tactics. To cite an example, when he arrived with his army at Orkardalr, where the jarls were faithfull to his rival, King Sverrir and his party surprised them in their manor and slaughtered them. When one escaped, the rider who was closest to reaching the escaped from behind was King Sverrir himself 35

\section{Sverrir the public speaker}

In public assemblies, the king is able to preside unhindered. No man spoke against the king at the thing of Hamar kaupang and men were eager to have his friendship after his first victories ${ }^{36}$. When his army was weary of the storm and his soldiers despaired, Sverrir was able to rally his followers and speak to them and had them vow to God, the Virgin and Saint Óláfr that they would complete their mission, which they did as if his voice had miraculous powers ${ }^{37}$. Again, when waiting in the forest for the battle with the superior force of Símun near Skriksvik he is able to rally his men to fight and eventually defeats his foe with few casulaties ${ }^{38}$. He also persuades the men of Sunndale to fight against King Magnús ${ }^{39}$. The men of Helsíngjaland, perhaps fearing the king's power of speech, try to bar him from joining the thing, but they do not succeed and Sverrir convinces the locals to supply his Birkibeinar, despite King Magnús's threats ${ }^{40}$.

Another important speech that King Sverrir held was the one before the assault at Steinbjörg:

"I need not detail before you the distresses in which you were involved before our arrival in this land, nor the few gains on which you have laid hands since. I can well infer from my own feelings that you will think the time is come when you should receive more profit than has yet been in our reach from the toil and great danger you have undergone. What we have won by the sword we have taken; entertainment here, money there, where we found it. But now there is a prize to be won in the town of Nidaros, somewhat more valuable than those for which we have often contended. In the town before us are King Magnús and Jarl Erling with man, barons and King's men;

\footnotetext{
35 Sverris saga, chapter 68.

36 Sverris saga, chapter 16.

37 Sverris saga, chapter 20.

38 Sverris saga, chapter 24 .

39 Sverris saga, chapter 25 .

40 Sverris saga, chapter 26 .
} 
and we may aim at greater honour than comes generally, I imagine, within our power. Victory will be hours, I feel sure, after the dream that has come to me. Let us now press forward the more eagerly, as we shall gather more fruit than hitherto. I will now make known to you what is to be gained: Whoever slays a baron, and can bring forward evidence of his deed, shall himself be a baron; and whatever title a man shall cause to be vacant, that title shall be his: he shall be King's man who slays a King's man, and he shall receive good honour besides. Such is the prize to be won, and I believe they have no certain knowledge of our movements. There is good reason to suppose that Fortune has abandoned them, and they have come to the end of their days; but we shall win victory and honour as it our due. Thus shall God decide between us and them. For a long time they have held possession of what is ours; maybe they will now lose what aforetime they wrongfully seized and will lose life as well. Let your first onset be fierce to the utmost; what remains will be done easily. Doubtless they are well steeped in drink, heavy with sleep, and so without resource; some of them are on board their ships, others here and there in the town, and they will scarcely know where to turn or what to do." 41

Some very important elements of the king's speech have been identified here. Firstly, he conjures his men's wrath against the adversaries by reminding them how much they suffered because of them and then promises his rich rewards to those who would prove themselves the bravest. Thirdly, he assures his men of the support of the divinity by appealing to God and by reassuring them that he had foreseen victory in a vision. Lastly, as the careful military strategist that he is, the King instructs his army how their superior tactic will bring an easy victory.

At the battle of the fields of Ila, King Sverrir held yet another speech in front of his troops. This time the king encourages his men to win or die bravely with a short anecdote and recalls the saying "Era sem kolvið kljúfi/ karl sá vegr at jarli (Carl that combats earl has other work/ Than cleaving wood for charcoal)" ${ }^{42}$. This proverb exposes King Sverrir's part of wisdom and could be traced to Hávamál.

After the victory and the demise of Jarl Erling, King Sverrir spoke to the soldiers again telling them how Archbishop Eystein had promised the

\footnotetext{
41 Sverris saga, chapter 35.

42 Sverris saga, chapter 47 .
} 
men of King Magnús that as soon as any of them would fall in battle their soul would enter Paradise, so if the archbishop had spoken the truth then all should rejoice that such a great man has become a saint. He also mentioned that "times are greatly changed, as you may see, and have taken a marvelous turn, when one man stands in the place of three - King, Earl, or archbishop - and I am that one"43. Sverrir identifies himself or is identified with three important roles, that may even correspond to the Trinity: the archbishop represents spiritual power, similarly with the Holy Ghost, and Sverrir does so by often calling for the help of God, Saint Óláfr or by relying on divine visions; secondly, Jarl Erling is the fatherly figure, the one who supports the king in his rule, this referring maybe to the importance of tradition and wisdom, which are greatly valued by Sverrir; and lastly, both Magnús and Sverrir are sons of royal descent, but Sverrir outright distances himself from Magnús by showing that his father, a mere baron (họfðingi) had made him king, while Sverrir relies on superior forces in his campaign.

On a different occasion, despite his other thoughts, when the king's men speak to him in assembly of attacking Nidaros, he does not act against their will, even though his visions warned him against that ${ }^{44}$, perhaps not wishing to do anything contrary to the desires of his soldiers (King Magnús, on the other hand is described as very violent in his speech at Trondheim, so much that "the yeomen imagined for a time that he meant to fall upon them and slay them"45). After the defeat King Sverrir foresaw, he speaks to his men, telling them:

"And now that our ill-luck has become known, we are chased and harassed wherever we go, and all who know of our wretchedness think we are nobody of consequence. Before this battle, victory was always on our side, and men all dreaded to come to blows with us. [...]The whole country, thane and thrall, will be upon us; our whole force will perish ingloriously, like all who fall in flight [...] we may yet so behave as to obtain great renown in our fall, since we shall fight against King Magnus himself. But if we win a victory over him, then will our strength increase thereby." 46

\footnotetext{
43 Sverris saga, chapter 38.

44 Sverris saga, chapter 27.

45 Sverris saga, chapter 69.

46 Sverris saga, chapter 29.
} 
This shows how important luck and victory were in the campaign for the throne. Defeat attracted defeat and bad luck even more bad luck, and the whole country could turn against them if the Birkibeinar did not rally and obtain a spectacular victory. The disaster of defeat is exacerbated in the king's speech, to show how crucial it was that and ideal monarch would be able to triumph over his adversaries. Retreat is an omen almost as inauspicious as defeat, on a different occasion we are told that "seldom are the fugitives inclined to face the enemy a second time, however valiant their resistance at first" ${ }^{\prime \prime}$. At Trondheim, Sverris saga tells us that King Magnús retreated despite having a force more than double that of the Birkibeiners, which "men remarked how evident it seemed..."48.

After the defeat of Jarl Erling, even his own son spoke against him as a tyrannical man, when trying to reassure his men of their correct choice to continue to support him ${ }^{49}$. Ultimately, it was after this great victory that "King Sverri's power grew to such a height that there was no one in Norway, except King Magnús and his men, who did not call him King. Hitherto wherever in market towns or other places great persons were present, if a man was called Birkibein it was thought a mark of contempt; henceforth the name was a title of honour, and the bearers of it were highly esteemed" 50 . Accession to the throne followed great military success, which confirms King Sverrir's model of monarch as that of a warrior-king.

After a similar speech to the ones described above but on this occasion held before the battle of Nordness, the Birkibeinar react with "loud applause" and his men exclaimed: "Well spoken! best of king [...] ever has your word proved false when you promised us victory! May the man be called dastard who will not rather fight and fall, sword in hand, than flee in cowardice and fear". At the naval battle in Sogn, King Sverrir left the protection of his flagship, the Mariusúdin, and took a boat "[...] Rowing from ship to ship, the King incited his men, and told them where they should attack. The King's words had good effect on the Birkibeinar, and they pressed forward boldly; and made a fierce onset..."51. Knowing the importance of his encouragement, the king left safety in order to encourage his men.

\footnotetext{
47 Sverris saga, chapter 92 .

48 Sverris saga, chapter 71 .

49 Sverris saga, chapter 39 .

50 Sverris saga, chapter 40 .

51 Sverris saga, chapter 91 .
} 


\section{Conclusions, Sverrir the holder of tradition}

The monarch must also make sure that celebrations and rituals are carried out. When Sverrir and his Birkibeinar pass Yule in Eystridali, the soon-to-be king senses that the yeomen are not eager to share their Yule banquet with them and devises a stratagem. He foresees that the locals would prepare the banquet for Yule if he pretended to go elsewhere ${ }^{52}$. When he does so, he is proved right, so the king is proven as a foreseer and a holder of traditions. Even after winning a great victory against his opponents and on the occasion of the death of Jarl Erling, Sverrir urges the Birkibeinar to observe all the necessary burial rituals. He "spoke in the manner then customary at the interment of noble persons. He first thanked the clergy for their chanting and beautiful service, and then all the people for their prayers and such gifts as each man was minded to add for the souls good of friend or neighbour. He exhorted each one carefully to perform for his intimate friend such kind offices as he himself would desire, declaring that he himself would find men to giver burial to those who had none to care for them" 53 . Tradition is not to be forsaken even when it comes to his direct enemies.

At Kaupang, in a conference with King Magnús, Sverrir reminds him of the tradition in Norway of double or triple joint rule and proposes peace in this conditions to his enemy, to which the yeomen that were present there with trade business "loudly applauded the king's speech and declared it excellent" 54 . This kind of populist approach got king Sverrir the support of the farmers and commoners, who probably preferred peace to civil war. Later in the conference, when King Magnús proposes a duel, Sverrir again points to tradition requiring men of noble origins (ríkismanna) to joust (turnreið) rather than duel "like those who have no followers" 55. King Sverrir again appears as the more knowledgeable one regarding dueling tradition as well.

In a different instance, when Eirik claimed that he also is a son of king Sigurd Munn and asked King Sverrir to permit him to undergo an ordeal by iron to prove this, Sverrir consented to the ordeal being carried

\footnotetext{
52 Sverris saga, chapter 22.

53 Sverris saga, chapter 38 .

54 Sverris saga, chapter 60.

55 Sverris saga, chapter 60 .
} 
out, proving that he trusts this legislative tradition ${ }^{56}$, and ignoring the danger of the possible discovery of a new claimant to the throne. Sverrir was also careful to recover the kingly symbols, crown and sceptre, after he defeated King Magnús at Bergen ${ }^{57}$.

King Sverrir also appears to be portrayed as a pure man in Sverris saga. Purity is a Christian virtue as well as a pagan one. Before defeating king Magnús in battle on St. Vitus day in 1184, King Sverrir had men on shore bring water so he could wash his hands and had his clotes brushed "as if he were about to attend a banquet" 58 , and when he returned to his flagship his warriors warned him not to touch the prow which had been recently smeared with tar ${ }^{59}$. After the battle, king Sverrir sought a place "where it was hoped the smell from the bodies might not be perceived" 60 and "obliged them [the men] and other yeomen to carry bodies to burial; he also allowed every man to perform as fully as he wished to last rites for his kinsmen or friends" 61 . This shows the king's repeated respect for the memory and funeral rites of his enemies. Regarding devotion to God, the nature of devotion in Sverris saga is much more direct, and closer to the old Viking beliefs, in which gods were addressed different requests on the occasion of religious ceremonies or other devotional acts. To give one more example, at the launching of the long ship that he dedicated to the Virgin Mary, king Sverrir makes gifts of priestly robes to the archbishop and has relics fixed on the new ship in order to bring "help and good fortune to the ship and the crew, and to all who sail upon it" . Also, King Sverrir uses his piety - for example, the episode at the beginning of his campaign for the throne of Norway, when, after prayer, Saint Óláfr himself protected and delivered him from danger - as a mean of legitimization. In contrast, what other, later sources, such as Konungs skuggsjá, recommend to kings stands out as much closer to the Christian European model of pious kingship.

\footnotetext{
56 Sverris saga, chapter 59.

57 Sverris saga, chapter 78 .

58 Sverris saga, chapter 88 .

59 Ibid.

60 Sverris saga, chapter 95 .

${ }^{61}$ Ibid.
} 


\section{References:}

Haki Antonsson, St. Magnús of Orkney, A Scandinavian Martyr-Cult in Context (Leiden: Brill, 2007).

Sverre Bagge, From Viking Stronghold to Christian Kingdom, State Formation in Norway, c. 900-1350 (Copenhagen: Museum Tusculanum Press, 2010).

-------, "Ideology and Propaganda in Sverris saga" Arkiv för nordisk filologi 108 (1993), 1-18.

Inger Ekrem, ed., Lars Boje Mortensen, ed., Peter Fisher, trans., Historia Norwegie (Copehangen: Museum Tusculanum Press, University of Copenhagen, 2006).

Anne-Sofie Gräslund, "Wolves, serpents, and birds, Their symbolic meaning in the Old Norse belief," in Andrén, Anders; Jennbert, Kristina et al., eds., Old Norse Religion in Long-Term Perspectives: Origins, Changes, and Interactions (Lund: Nordic Academic Press), 124-129.

Knut Helle, ed., The Cambridge History of Scandinavia. Prehistory to 1520 (Cambridge: CUP, 2008).

Katherine Holman, The A to $\mathrm{Z}$ of the Vikings (Plymouth: The Scarecrow Press, 2009).

Carl Phelpstead, ed., Devra Kunin, trans., A History of Norway and the Passion and Miracles of the Blessed Óláfr (London: University College London, 2001).

Bettina Sejbjerg Sommer, „The Norse Concept of Luck” Scandinavian Studies 79, 3 (Fall 2007), 275-294.

J. Stephton, trans., Sverrissaga - The Saga of King Sverri of Norway (London: David Nutt, 1899).

David Bond West, Biblical Allusions in Sverris Saga, MA dissertation in Medieval Icelandic Studies, Hugvísindasvið, Háskóli Íslands University, 2012.

\section{On-line source:}

Saint Sunniva of Bergen. CatholicSaints.Info. 4 July 2015. Web. 13 August 2015. http:// catholicsaints.info/tag/name-sunnifa/. 